\title{
More for the Mind and Its Legacy
}

\author{
[French translation: L'héritage de More for the Mind] \\ Steve Lurie \\ Canadian Mental Health Association Toronto Branch \\ David S. Goldbloom \\ Centre for Addiction and Mental Health
}

[La version française suit.]

\begin{abstract}
More For the Mind was published by the Canadian Mental Health Association in 1963. It reviewed the state of mental health services in Canada and called for transforming the delivery of mental health services from a neglected asylum-based system to a community-focused system where people could access services in general hospitals and the community. The article reviews the history of mental health services in Canada, the legacy of More for the Mind and the prospects for the reforms outlined in Changing Directions, Changing Lives.
\end{abstract}

Keywords: mental health services, history, reforms

\section{RÉSUMÉ}

More For the Mind est un important rapport publié en 1963 par l'Association canadienne pour la santé mentale dans lequel les auteurs examinaient l'état des services de santé mentale au Canada à cette époque. On y recommandait de transformer les services, alors offerts dans des asiles - un système lamentable -, pour les offrir dans les hôpitaux généraux et dans la communauté. Cet article donne une vue d'ensemble de l'histoire des services de santé mentale au Canada - en mettant l'accent sur l'héritage qu'a laissé More For the Mind-, puis explore les perspectives qu'offrent les réformes proposées récemment dans Changer les orientations, changer des vies.

Mots clés : services de santé mentale, histoire, réformes

Steve Lurie, Executive Director of CMHA Toronto Branch, Toronto, Ontario; Adjunct Professor Factor Inwentash Faculty of Social Work, University of Toronto, David S. Goldbloom, Senior Medical Advisor, Centre for Addiction and Mental Health, Toronto, Ontario; Professor, Department of Psychiatry, University of Toronto.

David Goldbloom was chair of the Mental Health Commission of Canada from 2012-2015.

Correspondence concerning this article should be addressed to Steve Lurie, CMHA Toronto Branch, 700 Lawrence Avenue W. \# 480 Toronto, Ontario M6A 3B4. Email: slurie@cmha-toronto.net 
In no other field except perhaps leprosy has there been as much confusion, misdirection and discrimination against the patient, as in mental illness. Control of the mentally ill has been regarded as the responsibility of the priests, the judges, the physicians, the philosophers, private charity and the state. Mentally ill patients have been lodged in jails, poor houses, hospitals, monasteries and pest houses. Mental illness, even today is all too often considered a crime to be punished, a sin to be expiated, a possessing demon to be exorcised, a disgrace to be hushed up, a personality weakness to be deplored or a welfare problem to be handled as cheaply as possible. (Tyhurst et al., 1963, p. 1)

The Canadian Mental Health Association published the "cri de coeur" cited above in 1963 in a landmark report called More for the Mind that documented generations of failure to assign equal priority to the development of mental health services compared to physical health services in Canada. In 2012, almost 60 years later, the Mental Health Commission of Canada (MHCC) published Changing Directions, Changing Lives, (Mental Health Commission of Canada, 2012) Canada's first ever national mental health strategy, which, like its predecessor report, proposes to transform Canada's mental health services and remedy generations of neglect by government.

This article examines the legacy of More For the Mind as well as its influence on the MHCC mental health strategy. The findings and recommendations of More for the Mind are reviewed and compared with the analysis and recommendations found in Changing Directions, Changing Lives. In 1984, one of the authors of this article published a review of More for the Mind and prospects for reform (Lurie, 1984). We will draw on this analysis to track the progress of reform over time and reflect on the challenges and opportunities posed by Changing Directions, Changing Lives to transform Canada's mental health system.

\section{A BRIEF HISTORY OF MENTAL HEALTH SERVICES IN CANADA}

In Canada during the 19th and early 20th centuries, the state and private charity assumed major responsibilities for the mentally ill. The state developed institutions that eventually shifted their focus from custodial care to medical or psychiatric care.

Griffin states that provincial authorities were at first concerned only with the segregation of the insane and the protection of society and property (Tyhurst et al., 1963). Canada's first mental hospital was a pest house (a quarantine-like facility) in St. John, New Brunswick, originally built to care for immigrants with cholera. The conversion from pest house to mental hospital occurred in 1836. A new facility, the Provincial Hospital for the Insane, was opened in 1848, which resulted in the abandonment of the original pest house mental hospital.

The ideas of Dorothea Dix and Thomas Kirkbride, American crusaders for the development of institutions to care for the mentally ill, influenced the development of provincial asylums throughout Canada in the second half of the 19th century. By the time the British North America Act was passed in 1867, resulting in the creation of the Dominion of Canada, care of the mentally ill was recognized as a distinct provincial responsibility and the running of asylums consumed a significant percentage of provinces' budgets. Professor Harvey Simmons claimed that asylums accounted for 75\% of Ontario's government spending at the beginning of the 20th century (S. Lurie, personal communication, 1990).

While the intent of provincial officials might have been to provide humane custodial care for the inmates of these asylums, the early history of Woodlands in British Columbia, now a provincial facility for people 
with intellectual disability, indicates that the opposite often occurred. (It should be noted that Canada's early asylums also housed people with developmental disabilities. The first institution for people with developmental disabilities was built in 1919 [Wolfensberger, 1980]).

Woodlands (or the Public Hospital for the Insane) was built next to a jail in 1878.

The building was very gloomy and austere. The windows were tiny and so high in the walls that residents had to stand on tables in order to see outside. As a result, standing on tables became one of the few, common and institutionalized pastimes of residents, dramatically underlining how psychotic appearing behaviour can be induced to people by the environment and the keepers... The institution was overcrowded no sooner than it was completed. Within a year, five of the 36 residents had died and soon all sorts of other atrocities came to light. Apparently this included several killings with some residents' bodies never being accounted for... Restraints were widely used, some of which resulted in death, as with one resident who died while squeezed into a closet. (Wolfensberger, 1980, p. 21)

Throughout the late 1800s and early 1900s, the populations of provincial asylums increased dramatically, and conditions continued to deteriorate. Dr. Clarence Hincks founded the Canadian Mental Health Association in 1918 and spent the next ten years investigating and reporting on the conditions of asylums in every Canadian province. (Lurie, 1984)

Dr. Hincks gave the following account of his investigation into conditions of provincial asylums in the Province of Manitoba. The asylum in Brandon had nine hundred patients and one doctor.

There was not one trained nurse in the entire institution. The male attendants were the roughest looking crew of men I have ever seen and because of the number of black eyes among the patients, it was evident that they used strong-arm methods for control. Over many of the beds was a heavy iron grating, and the patients beneath presented the appearance of caged wild animals. (CMHA, 1965)

Most patients were sent from the jails even though they had committed no offences, transported to the hospital tied down and fettered with "all the paraphernalia for restraint, manacles and chains" (CMHA, 1965). Dr. Hincks visited a place in Portage La Prairie that was worse than the Brandon asylum.

There was no medical man at all. At the end of one dark ward I saw a cupboard. I asked the Superintendent what the cupboard was used for... there on a hardwood floor was a naked woman with skin as white as snow and with a little square of towel. She placed it over her eyes because apparently she was unaccustomed to the light. And I asked the Superintendent, "How long has this lady been in this cupboard?" He said, "Two years." I said, "Has she been taken out?" He said, "Only once for less than ten minutes, she was restless!" And so he returned her to the cupboard. (CMHA, 1965)

Hincks conducted surveys and made recommendations on facilities, programs and staffing in every Canadian province. Over the next 20 years, his organization was indirectly responsible for the expenditure of millions of dollars in the mental health field. Hincks advocated small regional mental hospitals associated closely with departments of psychiatry of university medical facilities and the establishment of psychiatric units in general hospitals (Tyhurst et al., 1963).

\section{MORE FOR THE MIND}

More for the Mind recounts the development of Canadian psychiatric services between 1939 and 1963. The development of services in this period reflected a shift from legal and administrative concerns to the 
provision of medical and therapeutic care. By 1939, there was a renewed interest in psychological and social treatment methods, as well as the medical procedures involving the administration of insulin as well as psychosurgery. However, during World War II, the services in mental hospitals deteriorated (Lurie, 1984).

In 1948, the federal government awarded mental health grants to all Canadian provinces resulting in the upgrading of institutional facilities, programs and staff by 1959.

In the decade 1949 to 1959 the bed capacity in Canadian mental hospitals rose by nearly 18,000 . The number of patients on the books of mental institutions rose by over 18,000. Administrative staff doubled, professional personnel increased by three to four times, and the nursing staff became half as large again. Psychiatric services outside the mental hospital were greatly expanded, including the development of psychiatric treatment services in general hospitals, in outpatient and community clinics. (Tyhurst et al., 1963, p. 14)

While the number of beds did increase, the bed capacity per 100,000 population actually decreased between 1945 and 1963. Overcrowding was still a problem and the changes represented frantic attempts to meet a deficiency rather than implementation of a well planned program (Lurie, 1984).

In 1955, the National Scientific Planning Council of the Canadian Mental Health Association appointed the Committee on Psychiatric Services, chaired by Dr. J. S. Tyhurst, Professor of Psychiatry, University of British Columbia. It was given a mandate to

1. examine the existing mental health services in Canada, to explore and describe the existing patterns of care and the reasons why these patterns had developed the way they had; and especially, to find and expose the gaps in existing services.

2. devise fundamental new and more adequate patterns of diagnosis, treatment, care and prevention and to initiate a trend if possible towards changes in mental health services such innovations would create. (Tyhurst et al., 1963, p. 15)

The committee was composed entirely of psychiatrists, assisted by a group of consultants reflecting the disciplines of psychology, social work, nursing, occupational therapy, teaching and pastoral care. Over the next eight years, it reviewed previous studies, and commissioned briefs and papers by other professionals, culminating in the publication of More for the Mind in 1963, a report that was hailed as a blueprint for the development of mental health services in Canada.

\section{FINDINGS AND RECOMMENDATIONS OF MORE FOR THE MIND}

The Committee on Psychiatric Services reviewed the previous studies of provincial mental health services financed by the federal government and found that, in general, there had been a failure to act on the recommendations proposed. A number of reasons for this failure were identified as follows (Tyhurst et al., 1963):

- economic reasons, including the lack of money as well as the method of allocating and administering funds;

- tensions existing among psychiatric facilities services, lay organizations, governments, etc.;

- a lack of clearly defined principles for the development of psychiatric services;

- organizational problems in government health departments which attached a low priority to the development of mental health services; 
- public attitudes did not support a rapid expansion of mental health services;

- the supply of trained personnel caused delays in implementing changes.

Besides documenting reasons for the failure to act, the report describes existing treatment services - a system dominated by the provincial mental hospital. More for the Mind goes on to identify shortcomings of existing psychiatric services, including:

- isolated and oversized mental hospitals "attempting to care for 1,000 to 5,000 or more patients often in buildings that are obsolete and inadequate even by minimum health standards" (Tyhurst et al., 1963, p. 26);

- the lack of integration between the psychiatric hospital and other medical services;

- centralized government control of provincial mental hospitals which makes local communities less inclined to show the same interest, concern and responsibility for mental health problems as they normally display towards physical health needs;

- exclusion of mental health services from public and private medical insurance plans; and

- complexity of certification and committal procedures.

Concern was also expressed that mental health services needed to be expanded for Canada's aged population. There was also recognition that the medical treatment for the mentally ill was not the panacea to control mental illness. A strong commitment to psycho-social rehabilitation services would be required.

The central theme of More for the Mind was that "mental illness should be dealt with in precisely the same organizational, administrative framework as physical illness" (Tyhurst et al., 1963, p. 38). The report proposed

- Integration of psychiatric services with all other forms of medical care in order to reduce the stigma of segregation, raise the standards of care, and increase the acceptance of psychiatric illness by the medical profession.

- Regionalization of psychiatric services recognizing that "treatment should be provided as early as possible with as little dislocation and as much social restoration as possible" (Tyhurst et al., 1963, p. 40). The authors state that "a wide range of psychiatric services at the local level is necessary... Inpatient hospital services are seen as only one aspect of community mental health programs. Many patients may go through the complete illness episode without admission to hospital" (Tyhurst et al., 1963, p. 41)

- Decentralization that would place mental hospitals under local boards of directors.

- Continuity of care requiring "the closest possible co-operation and integration between the various services and professional staff” (Tyhurst et al., 1963, p. 44).

- Co-ordination of services in hospitals, clinics and other centres through the development of local mental health councils.

The subsequent 57 recommendations, which followed the theme and the five major proposals, covered a wide array of issues, including alcoholism and addiction services, the development of mental health services 
in industry, assessment, and treatment centres for children with emotional problems, development of psychogeriatric services, psychiatric consultation services and the establishment of domiciliary care facilities for people who do not require further clinical psychiatric treatment (Tyhurst et al., 1963).

A recurrent theme throughout the report was the development of community-based services resulting in a shift in emphasis from "inpatient services to community psychiatric services where a large proportion of psychological disorder can be treated without hospitalization" (Tyhurst et al., 1963, p. 15).

More for the Mind made a number of general comments related to the development of communitybased rehabilitation services and continuity of care. Perhaps the most significant is the suggestion that "the discharged patient should actually have a continuous personal relationship with some person in a particular agency" (Tyhurst et al., 1963, p. 75) in other words, a case manager.

\section{PROGRESS SINCE MORE FOR THE MIND}

Examining the findings and recommendations in 2014 suggests that while there has been some progress, major issues are still unresolved. Funding is still an issue. While there have been major investments in health care, particularly since 2004, the mental health share of health spending has continued to decline. For example, the mental health share of overall health spending in Ontario was $11.3 \%$ in 1979, 10 years after the majority of psychiatric beds were closed or transferred in the era of de-institutionalization. It has now declined to less than $7 \%$ of provincial health spending. Canada's spending on mental health is $7.2 \%$ of provincial health spending (WHO, 2011) and disproportionate to the burden of illness on individuals, families, and the economy.

As was the case in 1963, there is still considerable debate about planning principles for mental health systems, although the past 25 years have seen an increase in rhetoric in policy documents about recovery, patient or consumer-centred care, family involvement and shifting toward more of a community-focused system.

The stigma and discrimination identified in More for the Mind is still a problem. In 2006, the Senate Standing Committee on Social Affairs, Science and Technology issued its comprehensive report on mental illness in Canada, entitled Out of the Shadows at Last. Among its many recommendations - including a principal one that Canada needed to have a national mental health commission - it proposed that Canada develop an anti-stigma campaign similar to efforts in other countries and this has emerged as a key priority for the MHCC. Dr. Heather Stuart and colleagues have suggested that structural stigma contributes to underfunding of mental health systems, (Stuart, Alboreda-Florez, \& Sartorious, 2012) a finding eerily similar to More for the Mind's finding that public attitudes did not support expansion of mental health services.

The problem of large overcrowded mental asylums was largely resolved, although with unintended consequences in the absence of adequate community care. In 1963, the rated psychiatric bed capacity was 3.7 per 1,000 general population in Canada. By 1977, this had declined to 1.0 beds per 1,000. Patients in psychiatric institutional care declined from 79,707 to 24,362 in 1977, a three-fold decrease (Lurie, 1984).

However the shift toward a community-focused mental health system is still an elusive goal. In an audio recording just before his death in 1964, Hincks proposed: 
All we need is leadership by people who recognize the fact that we are in the ox-cart stage of development. In Amsterdam they haven't built a mental hospital in years because their mental health workers are working in the community, where they should be working... We could in the next few years open every mental institution in the country, bar none. We could divide the staff fifty-fifty between the institutions that are open and work in the community, where the real job's to be done. (CMHA, 1965)

For example, in 1993 the Ontario government proposed shifting the balance in mental health spending from $80 \%$ hospital-based and $20 \%$ community-based to $60 \%$ community-based and $40 \%$ hospital-based by 2003. This has yet to occur. Between 1987 and 2011, the community-based share of mental health spending in Ontario, as a reflection of overall health spending, did increase from $0.45 \%$ to $1.31 \%$ (Lurie, 2014) but there are still huge gaps in community care and waitlists for community mental health services and supportive housing. The same is true in all provinces and territories. While there are many examples of evidence-based community mental health services across the country, we do not have accessible community mental health systems in place as More for the Mind and Hincks proposed more than 50 years ago.

In Changing Directions, Changing Lives, the MHCC challenges the notion that deinstitutionalization, considered in isolation, is a public policy failure. The failure is the lack of investment in community services (Lurie, 2014).

Hospitals continue to be a major component of psychiatric care. An analysis of data from the Canadian Institute for Health Information (CIHI, 2014a) shows that general hospital discharges grew from 166,553 in 2003 to 182,655 in 2011, while psychiatric or specialty hospital separations declined slightly from 26,009 to 24,896 in the same period. CIHI data also shows that 1 in 10 people hospitalized for mental illness had repeat hospital stays and that rates increased in most communities across Canada between 2008 and 2011, (CIHI, 2014b) despite 30 years of research evidence showing the effectiveness of community-based supports such as case management, supportive housing, and assertive community treatment.

The Service Enhancement Evaluation Initiative (SEEI) studies in Ontario, which monitored the effects of enhanced funding for community mental health programs from 2004-2006, found that while there was increased capacity in some programs, "the newly enhanced community mental health system still does not have the capacity to serve all those in need. Demand increased in hospital emergency rooms even as early return rates to emergency rooms decreased" (CAMH, 2009).

Direct government control of psychiatric hospitals has been replaced by regionalization and, in some cases, changes in status to one similar to other public hospitals with local boards of directors. While psychiatric services are managed by the same authority responsible for general health care, mental health services do not receive the priority accorded to physical health care. For example, Ontario LHINS' (regional health authorities) spending on hospitals averaged over 60 cents on the health dollar while community mental health spending averaged 2.52 cents in 2010 (Province of Ontario Public Accounts, 2010).

Few jurisdictions in Canada have developed comprehensive mental health human resource strategies, although there has been an expansion of multidisciplinary teams for people with complex conditions (Assertive Community Treatment) and early psychosis. While there has been an expansion of general hospital psychiatry programs, there has been limited integration of mental health services with primary health care. Implementation of shared care, which has occurred over 20 years in Hamilton, Ontario, is an anomaly despite evidence of the benefits to family practice, and the challenges in chronic disease management for 
people living with long-term mental illnesses, which shows a premature mortality of 25-30 years compared to the general population.

During the 1980s and 1990s, many international jurisdictions developed policies and strategies to reform their mental health systems. The United Kingdom, Australia and New Zealand developed strategies to transform their mental health systems and increase funding for mental health services. The themes of recovery, stigma reduction, developing services for particular clinical populations, use of new technology, workforce training, improved performance measurement and research are common across jurisdictions. The role of government as funder, regulator and catalyst for regional or local system development, rather than service provider, is also common.

Many of Canada's provinces reviewed their mental health systems during this period and developed strategies for change. But by 2006, Canada remained the only member country of the Organisation for Economic Co-operation and Development without a national mental health strategy. Following their review of Canada's health system, the Senate Standing Committee on Social Affairs, Science and Technology took on a review of mental health services in Canada. Their report, Out of the Shadows At Last, published in 2006 (Government of Canada, 2006), echoed many of the themes of More for the Mind and also found that federal government performance was lagging in areas of their constitutional jurisdiction, such as services for immigrants and refugees, First Nations, Inuit and Metis peoples, as well as people incarcerated in the federal corrections system. The Senate Committee proposed the establishment of a mental health commission to act as a catalyst for reform and the creation of a $\$ 5.3$ billion mental health transition fund to accelerate the transformation towards community-based mental health care. The Mental Health Commission was established in 2007 and one of its key deliverables was the development of a mental health strategy for Canada.

\section{THE DEVELOPMENT OF A MENTAL HEALTH STRATEGY FOR CANADA}

The approach taken to developing a mental health strategy was deliberate and consultative. It drew on both existing national strategies in other jurisdictions as well as the experience and expertise from diverse groups of Canadians, including people with lived experience of mental health problems and illnesses, family caregivers, health professionals, and others. More formally, this process reflected a commitment to "civil society engagement," as described in detail in a recent publication by individuals directly involved in creating the national strategy (Mulvale, Chodos, Bartram, MacKinnon, \& Abud, 2014). In summary, the development of the national strategy involved a four-year process divided into two parts. The first part focused on the ultimate goals of a national strategy, since it was important to establish the destination before designing the means of getting there. This led to the publication of an interim report in 2009 entitled Toward Recovery and Well-Being: A Framework for a Mental Health Strategy (Mental Health Commission of Canada, 2009). This framework document established seven goals:

1. People of all ages living with mental health problems and illnesses are actively engaged and supported in their journey of recovery and well-being.

2. Mental health is promoted, and mental health problems and illnesses are prevented wherever possible.

3. The mental health system responds to the diverse needs of all people in Canada. 
4. The role of families in promoting well-being and providing care is recognized, and their needs are supported.

5. People have equitable and timely access to appropriate and effective programs, treatments, services and supports that are seamlessly integrated around their needs.

6. Actions are informed by the best evidence based on multiple sources of knowledge, outcomes are measured, and research is advanced.

7. People living with mental health problems and illnesses are fully included as valued members of Canadian society.

It concluded with a call to arms, asking for the entire mental health community to work together in creating a social movement to engage all citizens and advocate for change.

This interim report - which some provinces immediately began to use in developing their own mental health strategies - reflected enormous input from Canadians from coast to coast to coast, in the thousands, through in-person and online exchanges. Special efforts were made to insure that the voices of people with lived experience of mental illness and family caregivers were heard, in addition to other advocates and experts. The visionary founder and leader of the MHCC, Michael Kirby, felt that complete consensus on priorities and actions was an unachievable and even undesirable goal - that if everyone were happy, that was a sure sign nothing was being done. Rather, he advocated for endorsement of much, but not all, of the strategy by everyone, recognizing the diversity and divergence of views rendered unanimity elusive.

\section{CHANGING DIRECTIONS, CHANGING LIVES}

As expected, the framework document provoked a range of responses from high criticism to high praise, and the feedback was used to revise and re-shape the content into the second phase, Changing Directions, Changing Lives that contained more specific actions and indicators associated with six strategic directions:

1. Promote mental health across the lifespan in homes, schools, and workplaces, and prevent mental illness and suicide wherever possible.

2. Foster recovery and well-being for people of all ages living with mental health problems and illnesses, and uphold their rights.

3. Provide access to the right combination of services, treatments and supports, when and where people need them.

4. Reduce disparities in risk factors and access to mental health services, and strengthen the response to the needs of diverse communities and Northerners.

5. Work with First Nations, Inuit and Metis to address their mental health needs, acknowledging their distinct circumstances, rights and cultures.

6. Mobilize leadership, improve knowledge, and foster collaboration at all levels.

It also recognized historic funding declines, and called for an increase in the proportion of health spending that is devoted to mental health from 7 to $9 \%$ over 10 years, as well as a $2 \%$ increase from current levels in the percentage of social spending that is devoted to mental health. Acknowledging the need 
for efficiency and priority, it also recommended re-allocation of existing mental health spending to achieve better outcomes. Finally, it called on the private and philanthropic sectors to contribute resources to mental health (Mental Health Commission of Canada, 2012).

\section{LEGACY AND CHALLENGES}

Three years after its release, the national strategy's recommendations have yet to transform the landscape of mental health and mental illness in Canada. That is hardly surprising given the size of the problems and the scope of the change that is needed. Further, the MHCC recognized that the preliminary indicators embedded in the strategy would not be sufficient to measure change in the mental health system, and it has since funded a systems performance initiative to produce a meaningful menu of change measures. While some of the recommendations of the MHCC strategy require changing mindsets to implement more effective programs, such as the anti-stigma campaign Opening Minds, many of the actions for provincial and regional mental health systems will require substantial financial investments and an increase in the mental health share of health and social spending. The MHCC strategy does provide a catalyst for reform, but it remains to be seen whether there is sufficient political and bureaucratic will to make the investments required, especially with the looming reduction in federal health transfers to provincial and territorial governments beyond 2016.

However, unlike the situation for the equally laudable goals of the More for the Mind report, there is more opportunity now to follow up and follow through. First, Canadian society is more aware of, and more responsive to, the need to do a better job addressing mental illness and mental health in this country. People are more aware of the prevalence, impact, and cost. Inroads are being made against stigma and discrimination that serve as a barrier to both funding resources and accessing them. Political parties of every stripe and at every level are more openly acknowledging mental health as a priority. Second, the MHCC has established itself as a trusted adviser at the levels of federal, provincial and territorial governments, as well as a partner to other organizations and communities across the complex mental health landscape. It has demonstrated a capacity to deliver innovative initiatives, such as the ground breaking national study on homelessness and mental illness, At Home/Chez Soi, as well as the world's first national standards on psychological health and safety in the workplace.

More for the Mind offered 57 recommendations. In its Epilogue, it acknowledged that these reflected "the opinions of a group of psychiatrists rather than the joint and corporate views of representatives of the several different professional disciplines interested in the broad perspective of mental health." The MHCC strategy included not only such voices but also those of people with lived experience of mental illness and family caregivers. It conceded the need for more multi-disciplinary follow-up to the report, but offered no equivalent to the MHCC to oversee and to catalyze needed reform, despite the valuable role that the Canadian Mental Health Association plays across the country.

If major opportunities for reform arise once per century, then in the 19th century it was the creation of an asylum system across Canada to provide custodial care for people with mental illness. In the 20th century, in the transition out of asylums as the focal point of mental health care, More for the Mind generated noble, worthwhile goals for system transformation-developed by traditional and now-narrow expert consensus and implemented to varying degrees. In the 21 st century, the opportunity has risen anew with Changing 
Directions, Changing Lives, as well as with the existence of the MHCC, to try again to "get it right"-or at least "get it better," leveraging unprecedented public and political awareness and will to improve the lives of Canadians affected by mental health problems and illnesses. We cannot wait for the 22nd century.

\section{REFERENCES}

CAMH. (2009). SEEI: Moving in the right direction. https://knowledgex.camh.net/policy_health/mh_add_systems/ Documents/seei_moving_right_direction0309.pdf

CIHI. (2014a). Detailed Report A (Pan-Canadian). Microstrategy. http://apps.cihi.ca/mstrapp/asp/Main.aspx

CIHI. (2014b). Repeat hospital stays for mental illness. http://yourhealthsystem.cihi.ca/hsp/inbrief?lang=en

CMHA. (1965). Clarence Hincks: A Recollection, script of the CBC recording.

Government of Canada, The Standing Senate Committee on Science, Social Affairs and Technology. (2006). Out of the shadows at last: Transforming mental health and addiction services in Canada. http://www.parl.gc.ca/Content/ SEN/Committee/391/soci/rep/rep02may06-e.htm

Lurie, S. (1984). Mental health services in Canada: More for the mind-Have we got less? Issues in Canadian human services, Chapter 10. Toronto: OISE.

Lurie, S. (2014). Why can't Canada spend more on mental health?, Health, 6, 684-690. http://www.scirp.org/journal/ health http://dx.doi.org/10.4236/health.2014.68089

Mental Health Commission of Canada. (2009). Toward recovery and well being. Calgary, Alberta: Author.

Mental Health Commission of Canada. (2012). Changing directions, changing lives: The mental health strategy for Canada. Calgary, Alberta: Author.

Mulvale, G., Chodos, H., Bartram, M., MacKinnon, M. P., \& Abud, M. (2014). Engaging civil society through deliberative dialogue to create the first mental health strategy for Canada. Social Science \& Medicine, 123(December), 262-268. http://dx.doi.org/10.1016/j.socscimed.2014.07.029

Province of Ontario Public Accounts. (2010). http://www.fin.gov.on.ca/en/budget/paccts/2010/10_ar.html

Stuart, H., Alboreda-Florez, J., \& Sartorious, N. (2012). Paradigms lost: Fighting stigma and the lessons learned. Oxford University Press.

Tyhurst, J. S., Chalk, F. C. R., Lawson, F. S., McNeel, B. H., Roberts, C. A., Taylor, G. C.,...Griffin J. (1963). More for the mind. Toronto: Canadian Mental Health Association.

WHO. (2011). Mental health atlas: Country profiles. http:/www.who.int/mental_healthevidence/atlas/profiles/en/index. html

Wolfensberger, W. (1980). Review of the history of Woodlands. Canada's Mental Health, 28(3). 


\title{
L'héritage de More for the Mind
}

\author{
Steve Lurie \\ Association canadienne pour la santé mentale, filiale de Toronto \\ David S. Goldbloom \\ Centre de toxicomanie et de santé mentale
}

\begin{abstract}
RÉSUMÉ
More For the Mind est un important rapport publié en 1963 par l'Association canadienne pour la santé mentale dans lequel les auteurs examinaient l'état des services de santé mentale au Canada à cette époque. On y recommandait de transformer les services, alors offerts dans des asiles - un système lamentable -, pour les offrir dans les hôpitaux généraux et dans la communauté. Cet article donne une vue d'ensemble de l'histoire des services de santé mentale au Canada - en mettant l'accent sur l'héritage qu'a laissé More For the Mind-, puis explore les perspectives qu'offrent les réformes proposées récemment dans Changer les orientations, changer des vies.
\end{abstract}

Mots clés : services de santé mentale, histoire, réformes.

\begin{abstract}
More For the Mind was published by the Canadian Mental Health Association in 1963. It reviewed the state of mental health services in Canada and called for transforming the delivery of mental health services from a neglected asylum-based system to a community-focused system where people could access services in general hospitals and the community. The article reviews the history of mental health services in Canada, the legacy of More for the Mind and the prospects for the reforms outlined in Changing Directions, Changing Lives.
\end{abstract}

Keywords: mental health services, history, reforms.

Steve Lurie, directeur général, Filiale de Toronto de l'ACSM, Toronto, Ontario ; professeur auxiliaire, Factor Inwentash Faculty of Social Work, University of Toronto. David S. Goldbloom, conseiller médical en chef, Centre de toxicomanie et de santé mentale, Toronto, Ontario ; professeur, Department of Psychiatry, University of Toronto.

David Goldbloom a été président du conseil d'administration de la Commission de la santé mentale du Canada de 2012 à 2015.

Toute correspondance au sujet de cet article doit être adressée à Steve Lurie, Filiale de Toronto de l'ACSM, 700 Lawrence Avenue W., bureau 480, Toronto (Ontario) M6A 3B4. Courriel : slurie@cmha-toronto.net. 
Dans aucun autre domaine lié à la santé, à part peut-être ce qui touche la lèpre, il n'y a eu autant de confusion, de manipulation et de discrimination envers les patients que dans le cas de la maladie mentale. On a confié la responsabilité de contrôler les malades mentaux à des prêtres, à des juges, à des médecins, à des philosophes, à des organismes caritatifs et à l'État. Les patients psychiatriques ont été enfermés dans des prisons, des établissements délabrés, des hôpitaux et des institutions pour personnes atteintes de maladies infectieuses comme la peste. La maladie mentale, encore aujourd'hui, est trop souvent considérée comme un crime qui doit être puni, un péché qui doit être expié, un démon qui doit être exorcisé, une honte qu'il faut cacher, une faiblesse de la personnalité qu'il faut déplorer ou un problème social que l'on doit résoudre en y consacrant le moins d'argent possible. (Tyhurst et al., 1963, p. 1, n. t. ${ }^{1}$ )

Ces phrases, qui ressemblent à un véritable cri du cœur, sont tirées d'un rapport marquant de l'Association canadienne pour la santé mentale, intitulé More for the Mind, publié en 1963. On y documentait l'échec du système de santé canadien qui, pendant des décennies, n'avait jamais accordé la même importance au développement des services de santé mentale qu'à celui des services de santé physique. Presque 60 ans plus tard, la Commission de la santé mentale du Canada (CSMC) a publié en 2012 Changer les orientations, changer des vies (CSMC, 2012), la première stratégie en matière de santé mentale du Canada, qui, comme More for the Mind, propose de revoir les services de santé mentale et de remédier aux décennies de négligence des gouvernements.

Dans cet article, nous examinons l'héritage de More For the Mind ainsi que l'influence que le rapport a eue sur l'élaboration de la stratégie en matière de santé mentale conçue par la CSMC. Nous examinons l'analyse et les recommandations de More for the Mind, que nous comparons avec celles de Changer les orientations, changer des vies. L'un des auteurs de cet article a publié, en 1984, une critique de More for the Mind et des pistes de réforme du système (Lurie, 1984); nous puisons dans cette analyse pour suivre l'évolution de la réforme du système de santé mentale au Canada au cours des années et réfléchir à la fois sur les défis à relever et les occasions à saisir qu'offre Changer les orientations, changer des vies en cette matière.

\section{UN BREF HISTORIQUE DES SERVICES DE SANTÉ MENTALE AU CANADA}

Au Canada, au cours du $19^{\mathrm{e}}$ siècle et au début du $20^{\mathrm{e}}$ siècle, ce sont l'État et des organismes caritatifs, qui, en grande partie, s'occupaient des malades mentaux. L'État a ainsi créé des institutions qui, d'établissements de simple internement qu'elles étaient au départ, ont, avec le temps, mis de plus en plus l'accent sur les soins médicaux et psychiatriques.

Au départ, les préoccupations des autorités provinciales (responsables de la santé) se limitaient à retirer les malades mentaux de la société pour protéger les citoyens et la propriété (Tyhurst et al., 1963). Le premier hôpital psychiatrique du Canada a été un établissement dont la mission originale avait été d'accueillir les personnes atteintes de maladies infectieuses ; construit à Saint-Jean, au Nouveau-Brunswick, au départ pour les immigrants qui, atteints du choléra, y étaient mis en quarantaine, il a été transformé en hôpital

\footnotetext{
${ }^{1}$ Certaines des citations que comporte la version originale anglaise de cet article sont tirées d'ouvrages ayant déjà été traduits en français : quand c'est le cas, les citations présentées dans la version française sont tirées des traductions françaises de ces ouvrages. Sinon, les citations sont accompagnées de $n$. $t$. (notre traduction).
} 
psychiatrique en 1836. Cet établissement a été abandonné en 1848 quand un nouvel hôpital, le Provincial Hospital for the Insane, a ouvert ses portes en 1848.

Durant la seconde moitié du $19^{\mathrm{e}}$ siècle, les doctrines de Dorothea Dix et de Thomas Kirkbride, qui militaient en faveur d'institutions pour les malades mentaux, ont influencé la création d'asiles provinciaux partout au Canada. En 1867, avec l'adoption de l'Acte de l'Amérique du Nord britannique et la création du Dominion du Canada, les services de santé mentale ont été reconnus comme une compétence provinciale ; une partie importante des budgets provinciaux étaient alors consacrée à la gestion des asiles - le professeur Harvey Simmons avance par exemple que, au début du $20^{\mathrm{e}}$ siècle, $75 \%$ des dépenses du gouvernement de l'Ontario allaient aux asiles (S. Lurie, entretien personnel, 1990).

À cette époque, si les gouvernements avaient pour objectif d'héberger les malades mentaux dans des conditions les plus humaines possible, la réalité était tout autre, comme le montre l'histoire de Woodlands, un hôpital de la Colombie-Britannique, construit en 1878 - à côté d'une prison -, et aujourd'hui devenu une institution provinciale pour des personnes ayant une déficience intellectuelle. Notons d'ailleurs que les premiers asiles abritaient aussi des personnes ayant des troubles du développement, et que le premier établissement créé uniquement pour des personnes ayant des troubles du développement a été construit en 1919 (Wolfensberger, 1980).

Le bâtiment était austère et lugubre. Les fenêtres étaient très petites et si hautes que les résidents devaient se tenir debout sur des tables pour pouvoir regarder dehors. Monter sur des tables est ainsi devenu l'un des rares passe-temps des résidents, et cette « activité » a ainsi été reconnue « officiellement » comme étant associée à la maladie - ce qui montre de façon pathétique comment un comportement en apparence psychotique peut en fait être lié à l'environnement. [...] Dès son ouverture, l'institutions était surpeuplée, et, durant la première année seulement, 5 des 36 résidents y sont morts. On sait que les conditions de vie étaient épouvantables, et l'on croit que des meurtres y ont été commis, les corps de certains résidents n'ayant jamais retrouvés. [...] Divers moyens de contention étaient largement utilisés, et une personne y est par exemple morte enfermée dans un placard. (Wolfensberger, 1980, p. 21, n.t.)

Pendant tout le $18^{\mathrm{e}}$ siècle et au début du $19^{\mathrm{e}}$, la population des asiles provinciaux a augmenté de façon spectaculaire, et les conditions de vie ont continué de s'y détériorer. Le $\mathrm{D}^{\mathrm{r}}$ Clarence Hincks, fondateur de l'Association canadienne pour la santé mentale (ACSM), créée en en 1918, a enquêté, jusqu'en 1928, sur les conditions de vie dans les asiles de toutes les provinces (Lurie, 1984).

Voici entre autres ce qu'il a écrit après avoir visité un asile situé à Brandon, au Manitoba, une institution qui ne comptait que 1 médecin pour 900 patients.

Il n'y avait aucune infirmière. Les gardiens avaient un air brutal comme je n'en avais jamais vu, et, étant donné le nombre d'yeux au beurre noir que j'ai observés chez les patients, il était évident qu'ils utilisaient des méthodes musclées pour contrôler les résidents. Il y avait une grille en fer au-dessus de plusieurs lits, et les patients, couchés, avaient l'air d'animaux sauvages en cage. (ACSM, 1965, n.t.)

La plupart des patients arrivaient à l'asile envoyés par la direction de prisons où ils avaient été enfermés même s'ils n'avaient commis aucun délit ; ils étaient transférés ligotés, menottés et enchaînés (ACSM, 1965). Le $\mathrm{D}^{\mathrm{r}}$ Hincks rapporte ce qui suit sur l'asile de Portage La Prairie, un endroit pire encore que celui de Brandon.

Parmi le personnel, absolument personne n'avait la moindre compétence médicale. Au fond d'une salle sombre, j'ai vu un placard, et j'ai demandé au Superintendant à quoi cela servait. [...] une femme nue, dont 
la peau était blanche comme neige et qui n'avait qu'une serviette minuscule pour se couvrir, était étendue sur le plancher de bois. Elle se couvrait les yeux avec sa serviette parce que la lumière semblait l'éblouir. J'ai demandé au Superintendant : «Depuis combien de temps cette femme est-elle dans le placard ? »Il m'a répondu : « Deux ans. » J'ai dit : « En est-elle sortie de temps en temps ? » Il a répondu : « Seulement une fois, pendant 10 minutes, parce qu'elle était trop agitée. » Puis la femme a été de nouveau enfermée dans le placard. (ACSM, 1965, n.t.)

À la suite de ses enquêtes, le $\mathrm{D}^{\mathrm{r}}$ Hincks a fait des recommandations sur les institutions et le personnel des asiles ainsi que sur les programmes gouvernementaux en matière de santé mentale de toutes les provinces. Pendant les 20 années qui ont suivi ses rapports, l'Association canadienne pour la santé mentale a ainsi indirectement été à l'origine de millions de dollars de dépenses gouvernementales dans le domaine de la santé mentale. Le $\mathrm{D}^{\mathrm{r}}$ Hincks préconisait la création de petits hôpitaux psychiatriques régionaux, reliés aux institutions chapeautées par les départements universitaires de psychiatrie, de même que la mise en place d'unités psychiatriques dans les hôpitaux généraux (Tyhurst et al., 1963).

\section{MORE FOR THE MIND}

More for the Mind rend compte du développement des services offerts au Canada en matière de santé mentale de 1939 à 1963, et de l'évolution des principes sur lesquels ces services s'appuyaient : reliés au départ à des préoccupations d'ordres juridique et administratif, ils sont devenus avec le temps de véritables services de soins de santé. Cet aspect médical et thérapeutique était déjà présent en 1939, puisque l'on avait commencé à cette époque à s'intéresser à diverses méthodes de soins de nature psychologique et sociale ainsi qu'à des traitements médicaux, comme l'administration d'insuline et la psychochirurgie. Toutefois, pendant la Deuxième guerre mondiale, les services offerts dans les hôpitaux psychiatriques se sont détériorés (Lurie, 1984).

En 1948, le gouvernement fédéral a octroyé des subventions aux provinces, et, jusqu'en 1959, cela a permis d'améliorer la qualité des établissements et la compétence du personnel, et de mettre sur pied de meilleurs programmes.

En 1959, en comparaison avec 10 ans auparavant, le nombre de lits dans les hôpitaux psychiatriques du Canada avait augmenté d'environ 18000 et le nombre de patients hospitalisés d'un nombre plus grand encore. Le personnel administratif avait doublé, le nombre d'infirmières était une fois et demie plus élevé et le personnel professionnel avait été multiplié par trois ou quatre. Les services psychiatriques offerts hors des hôpitaux psychiatriques - dans les unités psychiatriques d'hôpitaux généraux et dans des cliniques externes et communautaires - se sont également beaucoup accrus durant cette période. (Tyhurst et al., 1963, p. 14, n. t.)

Par contre, si, de 1945 à 1963, le nombre de lits disponibles a augmenté, le nombre de lits par 100000 habitants, pour sa part, a diminué. La surpopulation des hôpitaux psychiatriques était donc toujours un problème, et les réformes réalisées durant cette période étaient en fait des tentatives quasi désespérées de corriger la situation plutôt que de véritables efforts pour mettre en place une politique adéquate et planifiée en conséquence (Lurie, 1984).

En 1955, le Conseil national de planification scientifique de l'ACSM a créé un comité de travail, présidé par le $\mathrm{D}^{\mathrm{r}} \mathrm{J}$. S. Tyhurst, professeur de psychiatrie à l'Université de la Colombie-Britannique, dont la mission était d'analyser les services psychiatriques ; son le mandat était plus précisément : 
1. d'examiner les services psychiatriques au Canada, pour décrire les pratiques et les normes utilisées et en expliquer l'origine afin de cerner leurs lacunes ;

2. d'élaborer de nouveaux modèles de diagnostics, de traitements, de soins et de prévention plus adéquats qui permettraient d'amorcer la transformation des services de santé mentale. (Tyhurst et al., 1963, p. 15, n. t.)

Le comité était composé de psychiatres, assistés par des consultants de diverses disciplines - psychologie, travail social, soins infirmiers, ergothérapie, enseignement et accompagnement pastoral. Pendant huit ans, ses membres ont recensé les études déjà réalisées dans le domaine et commandé des rapports et des analyses à des professionnels. Ce travail a mené à la publication, en 1963, de More for the Mind, un document que plusieurs ont salué comme étant le plan de développement des services de santé mentale au Canada que l'on attendait depuis longtemps.

\section{LES CONCLUSIONS ET LES RECOMMANDATIONS DE MORE FOR THE MIND}

Dans son rapport, le comité de travail en arrivait à la conclusion que les raisons qui expliquaient que la plupart des recommandations faites au cours des ans dans les études financées par le gouvernement fédéral sur les services de santé mentale n'avaient pas été appliquées étaient les suivantes (Tyhurst et al., 1963) :

- des questions économiques - le manque d'argent, mais aussi les méthodes d'allocation et de gestion des fonds ;

- des tensions existant entre les établissements de soins psychiatriques, les organismes laïques impliqués dans le domaine, les gouvernements et d'autres intervenants ;

- le manque de principes clairs sur lesquels appuyer le développement des services psychiatriques ;

- des problèmes organisationnels dans les divers ministères de la Santé, qui attachaient peu d'importance au développement des services psychiatriques ;

- le peu de soutien du public à l'importance du développement de services de santé mentale ;

- le manque de personnel qualifié.

En plus d'expliquer pourquoi les transformations souhaitées n'avaient pas été réalisées, le rapport traçait le portrait des services et de la façon dont ils étaient offerts. Le système, indiquait le rapport, était fondé presque uniquement sur les hôpitaux psychiatriques provinciaux, ce qui impliquait plusieurs problèmes :

- l'existence d'hôpitaux isolés et gigantesque « qui reçoivent de 1000 à 5000 patients - souvent même plus - et dont les installations sont vétustes et inadéquates même d'après des normes sanitaires minimales » (Tyhurst et al., 1963, p. 26, n. t.) ;

- le manque d'intégration des services des hôpitaux psychiatriques et des autres services médicaux ;

- le contrôle gouvernemental centralisé des hôpitaux psychiatriques, à cause duquel (entre autres) les collectivités locales n'avaient pas le même intérêt pour la santé mentale que pour la santé physique ;

- l'exclusion des soins de santé mentale des régimes publics et privés d'assurance maladie ;

- la complexité des procédures d'homologation et d'internement. 
Par ailleurs, le rapport mentionnait aussi la nécessité d'élargir les services de santé mentale à des populations comme les personnes âgées. On y affirmait également que les soins médicaux n'étaient pas une panacée en matière de maladies mentales et qu'il fallait, sur ce plan, mettre beaucoup plus d'accent sur la réhabilitation psychosociale.

Bref, l'idée centrale de More for the Mind, c'était que « la maladie mentale doit être traitée dans le même cadre organisationnel et administratif que la maladie physique » (Tyhurst et al., 1963, p. 38. n. t.). C'est pourquoi le rapport faisait ces cinq propositions :

- l'intégration des services psychiatriques dans l'ensemble des services médicaux afin de réduire la stigmatisation liée à la ségrégation des personnes souffrant de maladie mentale, de réduire les préjugés et les conceptions erronées face à la maladie mentale au sein de la profession médicale et de hausser les normes en matière de soins;

- la régionalisation des services psychiatriques, étant donné que «les traitements devraient être administrés le plus rapidement possible, en éloignant le moins possible les patients de leur communauté et en favorisant le plus possible la réinsertion sociale » (Tyhurst et al., 1963, p. 40, n. t.). Les auteurs affirmaient qu'il « faut offrir une vaste gamme de services psychiatriques à l'échelle locale. [...] Les services offerts aux patients hospitalisés doivent être considérés seulement comme l'un des aspects des programmes de santé mentale communautaire. De nombreux patients peuvent d'ailleurs vivre des épisodes de maladie mentale sans nécessairement être hospitalisés. » (Tyhurst et al., 1963, p. 41, n. t.);

- la décentralisation du système, les hôpitaux psychiatriques devant être placés sous l'autorité de conseils d'administration locaux ;

- une meilleure continuité dans la prestation des services, ce qui exige « une collaboration plus étroite entre les divers services et professionnels concernés » (Tyhurst et al., 1963, p. 44, n. t.) ;

- la coordination de l'ensemble des services offerts dans les hôpitaux, les cliniques et ailleurs, grâce à la création de conseils locaux de santé mentale.

En plus du principe de base et des 5 propositions principales qui en découlaient, le comité de travail faisait 57 recommandations touchant un grand nombre de questions : le traitement de l'alcoolisme et des dépendances, la mise en place de services de santé mentale dans les milieux de travail, l'élaboration mesures plus efficaces d'évaluation des services, la création de centres pour enfants souffrant de problèmes affectifs, la mise en place de services psychogériatriques et de services de consultation psychiatrique, et la prestation de soins à domicile pour les gens dont l'état ne nécessitait pas d'autres types de soins psychiatriques (Tyhurst et al., 1963).

L'un des thèmes récurrents du rapport était également la nécessité que des services soient offerts dans la communauté, ce qui n'était possible que si l'on cessait de croire qu'il fallait absolument hospitaliser les patients pour les traiter, et que si l'on prenait véritablement conscience qu'un très grand nombre de troubles mentaux peuvent être traités sans hospitalisation (Tyhurst et al., 1963, p. 15).

Les auteurs faisaient enfin des commentaires d'ordre plus général sur les services de réadaptation dans la communauté et sur la continuité des soins. Le rapport affirmait ainsi que « les patients, quand ils reçoivent 
leur congé de l'hôpital, doivent pouvoir maintenir un lien personnalisé avec un intervenant travaillant dans un centre de de santé » (Tyhurst et al., 1963, p. 75, n. t.) - ce que l'on appelle aujourd'hui un gestionnaire de cas.

\section{L'ÉVOLUTION DEPUIS MORE FOR THE MIND}

Quand on relit aujourd'hui les conclusions et les recommandations de More for the Mind, on voit que, si le système de santé mentale canadien a évolué, des questions majeures n'ont toujours pas été réglées. Le financement, par exemple, est encore un problème ; alors qu'il y a eu des investissements majeurs en santé, particulièrement depuis 2004, la part que la santé mentale occupe dans l'ensemble des dépenses de santé a continué de diminuer. En Ontario, par exemple, la proportion des dépenses de santé consacrée à la santé mentale était de 11,3\% en 1979, 10 ans après la fermeture de la majorité des lits en psychiatrie ou de leur transfert dans le cadre de la désinstitutionnalisation; or, cette proportion est maintenant de moins de $7 \%$. Les dépenses du Canada en santé mentale équivalent à 7,2\% des dépenses provinciales (OMS, 2011), ce qui est très peu quand on considère l'importance des effets de la maladie mentale sur les individus, leurs proches et l'économie.

Comme en 1963, les principes sur lesquels devrait s'appuyer le système de santé mentale sont encore l'objet de débats, même si, au cours des 25 dernières années, des concepts le rétablissement, les soins axés sur les patients ou les usagers, le rôle des proches et l'importance de la communauté sont devenus de plus en plus présents dans les études et les documents qui traitent de stratégie en matière de santé mentale.

La stigmatisation et la discrimination sont également encore un problème. En 2006, le Comité sénatorial permanent des affaires sociales, sciences et technologie a publié un rapport détaillé sur la santé mentale au Canada intitulé De l'ombre à la lumière. Parmi de nombreuses recommandations - dont la principale était que le Canada se dote d'une commission de la santé mentale -, le rapport proposait que le Canada mette sur pied une campagne anti-stigmatisation, comme d'autres pays l'avaient déjà fait, ce qui est d'ailleurs devenu une priorité de la CSMC dès sa création. Cela n'est pas un hasard : plusieurs chercheurs insistent sur l'importance de lutter contre la stigmatisation, puisque, selon certains, la stigmatisation structurelle de la maladie mentale est l'un des facteurs qui est encore aujourd'hui à l'origine de l'insuffisance du financement que les gouvernements consacrent aux systèmes de santé mentale (Stuart, Alboreda-Florez, et Sartorious, 2012) ; or, c'est une conclusion à laquelle arrivait déjà More for the Mind en 1963, puisque les auteurs y affirmaient que l'opinion publique - peu favorable au développement de services de santé mentale - était un élément qui freinait le développement pourtant nécessaire de ces services.

Par ailleurs, si le problème des gigantesques asiles surpeuplés a largement été résolu, cela a eu des conséquences importantes (que l'on n'avait pas prévues), puisque l'offre nécessaire de soins adéquats dans la communauté n'est pas devenue une réalité. En 1963, le taux de capacité d'accueil en psychiatrie était de 3,7 lits pour 1000 habitants au Canada; en 1997, ce chiffre avait diminué à 1,0 pour 1000 , ce qui est trois fois moins (Lurie, 1984).

Ainsi, le virage vers un système de santé mentale axé sur la communauté ne s'est pas fait, et l'objectif semble encore aujourd'hui loin d'être atteint. Dans un enregistrement audio réalisé en 1964, juste avant son décès, le $\mathrm{D}^{\mathrm{r}}$ Clarence Hincks affirmait pourtant : 
Ce qu'il faut, c'est que les gens reconnaissent que nous sommes encore à l'âge de pierre dans le domaine de la santé mentale. À Amsterdam, par exemple, on n'a pas construit d'hôpital psychiatrique depuis très longtemps. Pourquoi ? Parce que les travailleurs en santé mentale sont dans la communauté, là où ils doivent réellement faire leur travail. [...] Nous, nous pourrions, dans les années qui viennent, diviser en deux le personnel des établissements psychiatriques, et en affecter une des moitiés à des organismes présents dans la communauté, où sont les plus grands besoins. (ACSM, 1965, n. t.)

L'exemple de l'Ontario illustre bien que ce virage n'a pas été fait. En 1993, la province a envisagé de modifier la répartition de ses dépenses en santé mentale $-80 \%$ allaient alors aux hôpitaux et $20 \%$ à la santé mentale communautaire ; on souhaitait que, en 2003, $60 \%$ des dépenses soient consacrées à la santé communautaire et 40 \% aux hôpitaux. Pourtant, entre 1987 et 2011, la part du budget total des dépenses en santé consacrée aux soins communautaires a augmenté de $0,45 \%$ à 1,31 \% (Lurie, 2014), mais, aujourd'hui, l'écart entre les besoins et les services offerts est toujours énorme, et les listes d'attente pour des services de santé mentale communautaire ou des logements supervisés ne cessent de s'allonger. Et la situation est identique dans les autres provinces et territoires. Alors que, partout au pays, de nombreux exemples ont prouvé l'efficacité des services de santé mentale communautaire, le système de santé mentale axé sur la communauté que proposait More for the Mind il y a 50 ans n'existe toujours pas. Dans Changer les orientations, changer des vies, la CSMC remet ainsi en question le fait que la désinstitutionnalisation - quand on considère la stratégie en elle-même - a été une erreur stratégique ; l'erreur qui a été commise, explique-t-on, c'est que l'on n'a pas fait, à la suite de la désinstitutionnalisation, les investissements nécessaires dans les services communautaires (Lurie, 2014).

En effet, les hôpitaux sont encore une composante majeure du système de santé mentale. Des données de l'Institut canadien d'information sur la santé (ICIS, 2014a) montrent que le nombre de congés de l'hôpital, dans les hôpitaux généraux, a augmenté de 166 553, en 2003, à 182 655, en 2011, alors que, dans les hôpitaux psychiatriques ou spécialisés, ce nombre n'a que légèrement diminué de 26009 à 24896 au cours de la même période. Les chiffres indiquent aussi que 1 personnes hospitalisée pour maladie mentale sur 10 est par la suite de nouveau hospitalisée, et que ce taux a augmenté dans la plupart des communautés canadiennes de 2008 à 2011 (ICIS, 2014b), malgré le fait que, depuis 30 ans, on a démontré l'efficacité des mesures de soutien dans la communauté, comme la gestion de cas, les logements supervisés et le traitement communautaire dynamique.

En Ontario, grâce à la Service Enhancement Evaluation Initiative, on a réalisé des études pour évaluer les effets de la hausse du financement des programmes de santé mentale communautaire de 2004 à 2006, et les conclusions montrent que, même si l'accessibilité à certains programmes a été accrue, « le système de santé mentale communautaire, même après les améliorations qui ont été apportées, n'arrive toujours pas à offrir des services à tous ceux qui en ont besoin ; en effet, la demande de chambres dans les urgences des hôpitaux a augmenté, même si le taux de réadmissions hâtives à l'urgence après un congé a diminué » (CAMH, 2009, n.t.)

Par ailleurs, les hôpitaux psychiatriques ne sont plus sous l'autorité centralisée des gouvernements : la régionalisation des hôpitaux psychiatriques a été réalisée, et, dans certains cas, ceux-ci ont un statut semblable à celui des autres hôpitaux publics et sont gérés par un conseil d'administration. Mais, si les services psychiatriques sont dirigés par les responsables de l'ensemble des soins de santé, on n'accorde toujours pas 
aux services de santé mentale la même importance qu'aux soins de santé physique. Par exemple, en Ontario, les dépenses faites par les réseaux locaux d'intégration des services de santé dans les hôpitaux correspondaient en moyenne en 2010 à 60 cents sur un dollar/santé, alors que, dans le cas des dépenses en santé mentale communautaire, ce chiffre était en moyenne de 2,52 cents (Province of Ontario Public Accounts, 2010).

En matière de personnel, peu de collectivités publiques au Canada ont une stratégie globale de ressources humaines en santé mentale, même si le nombre d'équipes multidisciplinaires traitant les personnes souffrant de maladies complexes (traitement communautaire dynamique) et qui en sont aux premiers stades de la psychose se sont multipliées. Alors que le nombre de programmes de psychiatrie des hôpitaux généraux s'est accru, l'intégration des services de santé mentale et des soins de santé primaire est encore limitée. Par exemple, la pratique des soins partagés, qui existe depuis 20 ans à Hamilton, en Ontario, reste une exception au pays, alors que les avantages de cette approche en médecine familiale ont pourtant été démontrés, et que la gestion de la maladie chez les gens qui souffrent de maladies mentales chroniques, qui meurent prématurément de 25 à 30 ans plus tôt que le reste des Canadiens, pose un énorme défi.

Pendant les années 1980 et 1990, plusieurs pays ont élaboré des stratégies afin de revoir leur système de santé mentale ; c'est le cas du Royaume-Uni, de l'Australie et de la Nouvelle-Zélande, où l'on a également accru le financement des services de santé mentale. Dans ces pays, le rétablissement, la lutte contre la stigmatisation, la mise en place de services adaptés à différents types de populations cliniques, l'utilisation de nouvelles technologies, la formation adéquate de la main-d'œuvre, une meilleure évaluation du rendement et la recherche font maintenant partie de la réalité quotidienne. Les gouvernements n'y sont plus d'abord des prestataires de services, ils jouent plutôt le rôle de responsables du financement et de régulateur et de catalyseur du développement des systèmes régionaux ou locaux.

Plusieurs provinces canadiennes ont également revu leur système de santé mentale pendant cette période et adopté des stratégies pour le transformer. Mais, en 2006, le Canada restait le seul pays de l'Organisation de coopération et de développement économiques à ne pas avoir de stratégie nationale en matière de santé mentale. Après avoir fait un rapport sur le système de santé au Canada, le Comité sénatorial permanent des affaires sociales, sciences et technologie s'est penché sur les services de santé mentale au pays, et le rapport qui a résulté de cette étude, De l'ombre à la lumière, publié en 2006 (Gouvernement du Canada, 2006), en faisant écho à plusieurs des thèmes de More for the Mind, a conclu que l'action du gouvernement fédéral laissait à désirer dans plusieurs secteurs qui sont de ses compétences - les services offerts aux immigrants et aux réfugiés, aux membres des Premières nations, aux Inuits et aux Métis, de même qu'aux personnes incarcérées dans des pénitenciers fédéraux. Le Comité sénatorial a alors proposé d'une part la création d'une commission de la santé mentale qui agirait comme un catalyseur de la réforme à réaliser, et d'autre part la constitution d'un fonds de transition de 5,3 milliards de dollars pour soutenir la transformation du système de santé mentale en véritable système axé sur la communauté. Donnant suite au rapport, le gouvernement fédéral a créé en 2007 la Commission de la santé mentale du Canada, dont l'un des objectifs principaux était d'élaborer une stratégie nationale en matière de santé mentale pour le pays. 


\section{L'ÉLABORATION D'UNE STRATÉGIE NATIONALE EN MATIÈRE DE SANTÉ MENTALE}

La stratégie canadienne en matière de santé mentale a été mûrement réfléchie et a été le résultat de vastes consultations. La CSMC s'est inspirée à la fois des stratégies adoptées dans d'autres pays et de l'expérience et de l'expertise de nombreux Canadiens, dont des personnes ayant vécu ou vivant avec des problèmes de santé mentale et leurs proches ainsi que des professionnels de la santé. En termes plus officiels, la démarche avait pour but de refléter «l'engagement de la société civile», comme le décrit un ouvrage récent rédigé par des personnes ayant participé à l'élaboration de la stratégie (Mulvale, Chodos, Bartram, MacKinnon et Abud, 2014). L'élaboration de la stratégie s'est faite en deux étapes échelonnées sur quatre ans. Dans un premier temps, on a précisé l'objectif de la stratégie - puisqu'il est important de savoir où l'on veut aller avant de définir comment s'y rendre -, ce qui a mené à la publication, en 2009, d'un rapport intérimaire intitulé Vers le rétablissement et le bien-être-Cadre pour une stratégie nationale en matière de santé mentale au Canada (CSMC, 2009). Ce document définissait sept principes devant servir d'objectifs :

1. Les personnes de tout âge vivant avec des troubles mentaux ou une maladie mentale sont activement engagées et appuyées dans leur processus de rétablissement et d'atteinte du bien-être.

2. La promotion de la santé mentale est favorisée et les troubles mentaux ainsi que les maladies mentales sont évités lorsque c'est possible.

3. Le système de santé mentale répond aux besoins variés de toutes les personnes qui vivent au Canada.

4. Le rôle des familles dans la promotion du bien-être et la prestation de soins est reconnu, et leurs besoins sont pris en compte.

5. Les personnes ont un accès équitable et opportun à des programmes, à des services, à des traitements et à des formes de soutien appropriés, efficaces et véritablement intégrés qui tiennent compte de leurs besoins.

6. Les mesures prises sont fondées sur diverses sources de connaissances et de données probantes, les résultats sont mesurés et la recherche progresse.

7. Les personnes vivant avec des troubles mentaux ou une maladie mentale sont entièrement intégrées à titre de membres de la société.

Le rapport concluait par un appel à la mobilisation, afin que toutes les personnes directement touchées par les questions liées à la santé mentale s'attèlent à la tâche de créer un large mouvement social menant à la transformation du système de santé mentale.

Ce rapport intérimaire - que certaines provinces ont immédiatement utilisé pour concevoir leur propre stratégie - reflétait la contribution de nombreux Canadiens des quatre coins du pays qui s'étaient exprimés, en personne ou en ligne, au cours de milliers d'échanges de points de vue. La CSMC a fait des efforts particuliers pour s'assurer que la voix des personnes vivant avec des troubles mentaux ou une maladie mentale et celle de leurs proches soient entendues et s'ajoutent à celle d'intervenants et d'experts. Selon Michael Kirby, fondateur de la Commission, il ne fallait pas viser un parfait consensus sur les priorités à définir et les mesures à mettre en place : cela aurait été un objectif inatteignable, et ce n'était pas non plus souhaitable, 
puisque, étant donné la diversité des points de vue, dont certains étaient totalement opposés, il était impossible de créer l'unanimité. En fait, selon, Michael Kirby, si, à la fin du processus, on constatait que tout le monde était satisfait, cela signifierait que la démarche aurait été vaine ; il fallait donc viser une stratégie dont la plus grande partie satisferait l'ensemble des participants.

\section{CHANGER LES ORIENTATIONS, CHANGER DES VIES}

Tel que prévu, le rapport intérimaire a suscité de nombreuses réactions - allant de la critique la plus dure aux éloges les plus dithyrambiques -, dont la CSMC a tenu compte pour, dans une deuxième étape, en arriver à produire la stratégie en tant que telle. Cette stratégie est décrite dans le document Changer les orientations, changer des vies, qui définit, avec des mesures précises à mettre en place et des indicateurs liés aux tâches à accomplir six orientations stratégiques :

1. Promouvoir la santé mentale tout au long de la vie à la maison, en milieu scolaire ou au travail et prévenir le plus possible les maladies mentales et le suicide.

2. Promouvoir le rétablissement et le bien-être et défendre les droits des personnes de tout âge ayant des troubles mentaux ou une maladie mentale.

3. Donner accès à la bonne combinaison de services, de traitements et de formes de soutien en temps opportun, là où les personnes en ont besoin.

4. Réduire les inégalités en ce qui a trait aux facteurs de risque et à l'accès aux services en santé mentale et mieux répondre aux besoins des diverses communautés ainsi qu'à ceux des communautés du Nord.

5. Travailler avec les Premières nations, les Inuits et les Métis pour répondre aux besoins distincts de ces populations en matière de santé mentale en reconnaissant le caractère unique de leur situation, leurs droits et leur culture.

6. Mobiliser le leadership, améliorer les connaissances et favoriser la collaboration à tous les niveaux.

On fait également état, dans le document, du déclin du financement consacré à la santé mentale au cours des années, et l'on appelle à une hausse de $7 \%$ à $9 \%$ au cours des 10 prochaines années de la part du budget allouée à la santé mentale dans le financement de la santé ; on demande également une augmentation de 2 points de pourcentage de la part du budget allouée à la santé mentale dans le financement des programmes sociaux. De plus, pour que les différentes mesures soient appliquées selon certaines priorités et de façon efficace, on recommande d'allouer différemment des sommes faisant partie des budgets actuels. Enfin, on fait appel à des contributions du secteur privé et d'organismes philanthropiques (CSMC, 2012).

\section{HÉRITAGE ET DÉFIS}

Trois ans après la publication de la Stratégie, celle-ci n'a pas encore vraiment modifié le paysage de la santé mentale et de la maladie mentale au Canada - ce qui n'est pas vraiment surprenant étant donné l'ampleur des problèmes à résoudre et l'étendue des changements à réaliser. De plus, la CSMC était consciente que les indicateurs inclus dans la Stratégie ne seraient pas suffisants pour permettre de bien évaluer 
les progrès qui seraient accomplis, et elle a depuis financé un projet dont l'objectif est d'élaborer des mesures plus rigoureuses des changements qui se font. Par ailleurs, il faut noter, d'une part, que certaines des recommandations impliquent un changement des mentalités - c'est dans ce but que la Stratégie a recommandé l'organisation d'une campagne anti-stigmatisation ( « Changer les mentalités ») -, et, d'autre part, que plusieurs des mesures qui touchent les systèmes de santé provinciaux ou régionaux exigeront des investissements financiers substantiels et une hausse de la part consacrée à la santé mentale dans les budgets alloués à la santé et aux programmes sociaux. De plus, si la Stratégie joue le rôle de catalyseur des réformes à faire, celles-ci ne pourront être réalisées sans la volonté politique et bureaucratique essentielle à leur mise en place, surtout dans le cadre des réductions qui ont été annoncées des transferts fédéraux en santé aux gouvernements provinciaux et territoriaux après 2016.

Toutefois, quand on compare la situation actuelle à celle qui prévalait au moment de la publication de More for the Mind, on ne peut qu'affirmer que le contexte est beaucoup plus favorable aujourd'hui. Premièrement, la société canadienne est plus sensibilisée - et plus ouverte - à la nécessité, pour la collectivité, de mieux répondre aux besoins des citoyens en matière de santé mentale et de maladie mentale : les gens sont plus conscients de la prévalence, des impacts et des coûts de la maladie mentale; on observe ainsi des progrès dans la lutte contre la stigmatisation et la discrimination, deux obstacles à la hausse du financement des ressources et à une plus grande liberté d'accès aux services ; et les partis politiques de toutes les tendances et à tous les niveaux reconnaissent maintenant plus ouvertement que la santé mentale doit être une priorité des gouvernements. Deuxièmement, les gouvernements fédéral, provinciaux et territoriaux, de même que les organisations et l'ensemble des intervenants du paysage complexe de la santé mentale reconnaissent aujourd'hui la CSMC comme un organisme de référence incontournable ; la Commission a également démontré sa capacité de mettre sur pied des projets novateurs, comme celui qui a mené à l'élaboration des normes nationales sur la santé et la sécurité psychologiques en milieu de travail (une première mondiale), ou encore l'audacieuse étude nationale «At Home/Chez Soi » sur la santé mentale et l'itinérance.

Par ailleurs, les auteurs de More for the Mind reconnaissaient que les 57 recommandations du rapport reflétaient l'opinion d'un groupe de psychiatres plutôt que la position officielle des nombreuses professions concernées de près ou de loin par le domaine de la santé mentale. Pour concevoir la Stratégie, la CSMC, pour sa part, a consulté tous ces spécialistes, mais également de nombreuses personnes vivant avec un problème de santé mentale ainsi que leurs proches. L'ACSM, qui a été à l'origine de More for the Mind, reconnaissait ainsi la nécessité de l'apport de spécialistes de plus nombreuses disciplines pour produire un rapport visant à transformer le système de santé mentale, mais elle n'avait pas les mêmes moyens de la CSMC pour pouvoir, comme cette dernière, chapeauter et catalyser les changements, et ce, même si elle a joué et joue encore un rôle précieux partout au Canada en matière de santé mentale.

S'il n'y a, à chaque siècle, qu'une seule véritable occasion de réaliser des réformes majeures, alors on peut dire que le $19^{\mathrm{e}}$ siècle a été, au Canada, celui de la mise sur pied d'asiles qui ont recueilli des milliers de personnes souffrant de maladie mentale. Au $20^{\mathrm{e}}$ siècle, dans le processus de transition entre les asiles et la reconnaissance de la nécessité d'offrir de véritables soins aux personnes ayant un problème de santé mentale, More for the Mind a été une étape capitale, en définissant des objectifs louables et sérieux pour une transformation du système de santé mentale - grâce au consensus d'un certain nombre d'experts (que l'on jugerait aujourd'hui comme trop restreint) -, et dont certaine recommandations, et dans diverses mesures, 
ont été appliquées. Au $21^{\mathrm{e}}$ siècle, entre autres grâce à l'existence de CSMC, nous avons l'occasion, avec la publication de Changer les orientations, changer des vies, de réaliser de véritables changements - ou, à tout le moins, de mieux faire les changements nécessaires - en tirant profit d'une sensibilisation des citoyens et d'une volonté politique sans précédant au pays, afin de réellement améliorer la vie des Canadiens qui vivent avec un trouble mental ou une maladie mentale. Cela est trop important pour que nous attendions jusqu'au $22^{\mathrm{e}}$ siècle.

\section{RÉFÉRENCES}

ACSM (Association canadienne pour la santé mentale). 1965. Clarence Hincks: A Recollection, script of the CBC recording.

CAMH (Centre de toxicomanie et de santé mentale). 2009. SEEI: Moving in the right direction. https://knowledgex. camh.net/policy_health/mh_add_systems/Documents/seei_moving_right_direction0309.pdf

CSMC (Commission de la santé mentale du Canada). 2009. Vers le rétablissement et le bien-être-Cadre pour une stratégie nationale en matière de santé mentale au Canada. Calgary, Alberta.

CSMC (Commission de la santé mentale du Canada). 2012. Changer les orientations, changer des vies - Stratégie en matière de santé mentale pour le Canada. Calgary, Alberta.

Gouvernement du Canada, Comité sénatorial permanent des affaires sociales, sciences et technologie. 2006. De l'ombre à la lumière - La transformation des services concernant la santé mentale, la maladie mentale et la toxicomanie au Canada. http://www.parl.gc.ca/Content/SEN/Committee/391/soci/rep/rep02may06-e.htm

ICIS (Institut canadien d'information sur la santé) 2014a. Detailed Report A (Pan-Canadian). Microstrategy. http:// apps.cihi.ca/mstrapp/asp/Main.aspx

ICIS (Institut canadien d'information sur la santé) 2014b. Repeat hospital stays for mental illness. http://yourhealthsystem. cihi.ca/hsp/inbrief?lang=en

Lurie, S. 1984. « Mental health services in Canada: More for the mind-Have we got less? », dans Issues in Canadian human services, chapitre 10. Toronto : OISE.

Lurie, S. 2014. « Why can’t Canada spend more on mental health? », Health, 6, p. 684-690. http://www.scirp.org/ journal/health http://dx.doi.org/10.4236/health.2014.68089

Mulvale, G., Chodos, H., Bartram, M., MacKinnon, M. P., et Abud, M. 2014. « Engaging civil society through deliberative dialogue to create the first mental health strategy for Canada », Social Science \& Medicine, vol. 123 (décembre), p. 262-268. http://dx.doi.org/10.1016/j.socscimed.2014.07.029

OMS (Organisation mondiale de la santé). 2011. Mental health atlas: Country profiles. http:/www.who.int/mental_ healthevidence/atlas/profiles/en/index.html

Province of Ontario Public Accounts. 2010. http://www.fin.gov.on.ca/en/budget/paccts/2010/10_ar.html

Stuart, H., Alboreda-Florez, J., et Sartorious, N. 2012. Paradigms lost: Fighting stigma and the lessons learned. Oxford University Press.

Tyhurst, J. S., Chalk, F. C. R., Lawson, F. S., McNeel, B. H., Roberts, C. A., Taylor, G. C., ... et Griffin J. 1963. More for the mind. Toronto : Canadian Mental Health Association.

Wolfensberger, W. 1980. «Review of the history of Woodlands », Canada's Mental Health, vol. 28, nº 3. 